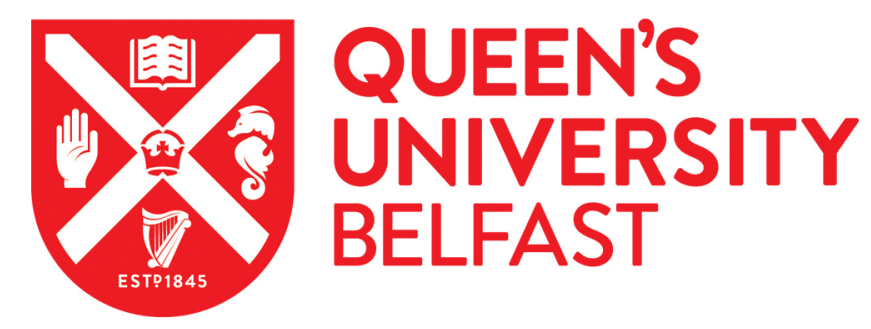

\title{
Radiological evaluation of by-products used in construction and alternative applications; Part I. - preparation of natural radioactivity database
}

Sas, Z., Doherty, R., Kovacs, T., Soutsos, M., Sha, W., \& Schroeyers, W. (2017). Radiological evaluation of byproducts used in construction and alternative applications; Part I. - preparation of natural radioactivity database. Construction and Building Materials, 150, 227-237. https://doi.org/10.1016/j.conbuildmat.2017.05.167

Published in:

Construction and Building Materials

Document Version:

Publisher's PDF, also known as Version of record

Queen's University Belfast - Research Portal:

Link to publication record in Queen's University Belfast Research Portal

\section{General rights}

Copyright for the publications made accessible via the Queen's University Belfast Research Portal is retained by the author(s) and / or other copyright owners and it is a condition of accessing these publications that users recognise and abide by the legal requirements associated with these rights.

Take down policy

The Research Portal is Queen's institutional repository that provides access to Queen's research output. Every effort has been made to ensure that content in the Research Portal does not infringe any person's rights, or applicable UK laws. If you discover content in the

Research Portal that you believe breaches copyright or violates any law, please contact openaccess@qub.ac.uk. 


\section{Radiological evaluation of by-products used in construction and alternative applications; Part I. Preparation of a...}

Article in Construction and Building Materials · April 2017

DOI: 10.1016/j.conbuildmat.2017.05.167

CITATIONS

0

6 authors, including:

\section{Zoltan Sas}

Queen's University Belfast

23 PUBLICATIONS 50 CITATIONS

SEE PROFILE
READS

5

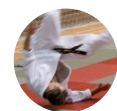

\section{Rory Doherty}

Queen's University Belfast

45 PUBLICATIONS 138 CITATIONS

SEE PROFILE

Some of the authors of this publication are also working on these related projects: 


\title{
Radiological evaluation of by-products used in construction and alternative applications; Part I. Preparation of a natural radioactivity database
}

\author{
Z. Sas ${ }^{\text {a,*, R. Doherty }}{ }^{\text {a }}$, T. Kovacs ${ }^{\text {b }}$, M. Soutsos ${ }^{\text {a }}$, W. Sha ${ }^{\text {a }}$, W. Schroeyers ${ }^{c}$ \\ a School of Natural and Built Environment, Queen's University Belfast, David Keir Bldg., 39-123 Stranmillis Rd, Belfast BT9 5AG, United Kingdom \\ ${ }^{\mathrm{b}}$ Institute of Radiochemistry and Radioecology, University of Pannonia, 10 Egyetem str, Veszprem H-8200, Hungary \\ ${ }^{\mathrm{c}} \mathrm{CMK}$, Nuclear Technological Centre (NuTeC), Faculty of Engineering Technology, Hasselt University, Agoralaan Bldg. H, B-3590, Diepenbeek, Belgium
}

\section{H I G H L I G H T S}

- Manual datamining was used to gather separately reported sample information.

- 431 by-products and 1095 construction materials were collected from 48 countries.

- Ra-226, Th-232 content were 2.00 and 2.11 times higher in the case of by-products.

- Ra equivalent concentration was 1.86 times higher in the case of by-products.

- I-index $>1.0$ in the event of $17 \%$ of construction materials; $58 \%$ of by-products.

\section{A R T I C L E I N F O}

\section{Article history:}

Received 27 January 2017

Received in revised form 6 May 2017

Accepted 21 May 2017

\section{Keywords:}

By-products

Building materials

Reuse

Natural radiation

Database

I-index

Mixing

\begin{abstract}
A B S T R A C T
To get an insight into the radiological features of potentially reusable by-products in the construction industry a review of the reported scientific data is necessary. This study is based on the continuously growing database of the By-BM (H2020-MSCA-IF-2015) project (By-products for Building Materials). Selection criteria were defined for manual data mining in such a way to avoid the collection of too heterogeneous datasets. Currently, the By-BM database contains individual data of about 431 by-products and 1095 construction and raw materials. The By-BM database only consists out of measurement information on individual samples and not out of processed data that only gives a rough summary (such as only a range or average) of experimental results. As a consequence of the statistical analysis of the data, it was found that in the case of the construction materials the natural isotope content had a wider distribution than the by-products. However, the average of the Ra-226, Th-232 and K-40 contents of reported by-products were $2.00,2.11$ and 0.48 , while the median was found $1.97,1.24$ and 0.53 times higher than the construction materials, respectively. The calculated Radium equivalent concertation was greater than the accepted value for residential properties of $370 \mathrm{~Bq} / \mathrm{kg}$ in the event of $10.3 \%$ of total construction materials and $42.4 \%$ of by-products, while the I-indexes were above 1.0 index value with $17.3 \%$ and $58.2 \%$, respectively. From the obtained data, it can be concluded that the reuse of industrial by-products in construction materials for residential purposes, without due diligence, can pose elevated risks to residents as a result of their high-volume usage.
\end{abstract}

(c) 2017 Elsevier Ltd. All rights reserved.

\section{Introduction}

The depletion of primary raw materials requires the development of new eco-innovative construction materials based on secondary resources. To counter global warming, low $\mathrm{CO}_{2}$ emissions are a requirement to produce these new types of construction

\footnotetext{
* Corresponding author.

E-mail address: z.sas@qub.ac.uk (Z. Sas).
}

materials. The urgent investigation of reuse of by-products is essential to enable new materials to be safely and efficiently integrated into new and refurbished buildings. The revised European Union's Waste Framework Directive with its objective to reach $70 \%$ of reuse, recycling and other forms of material recovery represents the main European policy driver [1]. In October 2014 the leaders of EU (European Union) agreed to a target of $40 \%$ reduction in greenhouse gas emissions by 2030 (based on 1990 levels). This resource efficient approach is central to the circular economy. 
The "end of pipe" concept is replaced by the concept of zero waste and the circular economy where waste production is avoided through proper design of materials, products, systems and business models resulting in many "cascades" or cycles of use. [2]. The urgent investigation of reuse of by-products is essential to enable new materials to be safely and efficiently integrated into new and refurbished buildings. Geopolymers can be alternative low-carbon binders (produced with the reuse of industrial wastes that are produced in large quantities). The properties of geopolymers are adjustable in the function production method $[3,4]$. These materials are very promising for replacing traditional construction materials and offer a solution to the immobilisation of toxic materials and radioactive wastes as well as the treatment of residues [5]. Construction materials can be produced directly from natural materials e.g. rocks, granite, gypsum, clay, etc. or by means of reuse of industrial by-products such as fly ash [6,7], bottom ash [8], phosphogypsum [9], steel slag [10], red mud [11], etc. The minerals contain terrestrial radionuclides from natural origin (U-238 and Th-232 series, furthermore K-40 and their progenies) which do not cause significantly higher radiation exposure than normal background levels. In soils, the current worldwide average activity concentration of $\mathrm{K}-40$ is $412 \mathrm{~Bq} / \mathrm{kg}, 33 \mathrm{~Bq} / \mathrm{kg}$ for $\mathrm{U}-238,32 \mathrm{~Bq} / \mathrm{kg}$ for Ra-226 and $45 \mathrm{~Bq} / \mathrm{kg}$ for Th-232 [12]. In the case of the construction materials, the reported world average values are $500 \mathrm{~Bq} / \mathrm{kg}, 50 \mathrm{~Bq} / \mathrm{kg}, 50 \mathrm{~Bq} / \mathrm{kg}$ for $\mathrm{K}-40, \mathrm{Ra}-226$, and $\mathrm{Th}-232$, respectively [13]. Although the reported average activity concentrations for construction materials are relatively small, significant variation can be found from region to region. In some cases, an elevated level of natural radionuclides of building materials causes significantly enhanced exposure on residents [8]. The radiation exposure originated from residential construction materials is a significant environmental factor on residents and critical receptors such as infants or the elderly that can spend $80 \%$ or even more time under indoor conditions [12]. The chronic exposure to small doses of ionising radiation can increase the risk of health damage of people, which may occur decades after the exposure [14]. The two most important exposure pathways for indoor exposure are:

1. External exposure: direct exposure of residents to gamma radiation from the naturally occurring radionuclides contained in the building materials.

2. Internal exposure: The inhaled radon (radioactive noble gas) and its progenies significantly augment the risk of the evolution of pulmonary cancer (2nd risk after smoking) [15]. Radon can exhale from the soil and also from the building materials and accumulate in poorly aerated spaces, such as mines or even in buildings. The radon is the major contributor to the ionising radiation dose received by most of the population. However, the primary source of the radon is the Ra-226 content of soil. The building materials also contribute to indoor radon depending on their Ra-226 content, porosity, and permeability.

This study is based on the continuously growing worldwide database of the By-BM (H2020-MSCA-IF-2015) project. The aim of cross-disciplinary By-BM (H2020-MSCA-IF-2015) project is to characterise the mechanical and also the radiological parameters of constituents and the prepared geopolymers (inorganic, synthetic building materials) made from industrial by-products $[16,17]$. To draw conclusions from scientific data available in the literature regarding the content of natural radionuclides of commercially available or newly developed construction materials and about the suitability of industrial by-products for use in building materials, it is important to gather the data in a database that allow their statistical analysis and visualisation. For NORM (Naturally Occurring Radioactive Materials) only a few databases exist e.g. NORM database of COST Action TU1301 NORM4Building [18] and NORM database of NIRS (National Institute of Radiological Sciences, Japan) [19]. These databases are accessible online, but a drawback of these databases is that the reported information is generally, available as a range or average values of samples that are not statistically related. This aspect does not enable further statistical analysis for visitors. In the case of the database constructed by Trevisi et al. of natural radioactivity in building materials in the European Union, information about more than 8000 samples was imported, evaluated and published [20].

The aims of the current study:

- Establishment of selection criteria to create a worldwide database of the natural radionuclide content of construction and raw materials and furthermore, industrial by-products

- The database only consists out of measurement information on individual samples and not out of processed data that only gives a rough summary (such as only ranges or average) of statistical unrelated experimental results.

- Statistical analysis of the reported data to obtain main statistical features (min, max, average, 1st quartile, median, 3rd quartile, distribution characteristic, box-and-whisker plot)

- Visualisation of large number of data to facilitate the comparison of different material categories

- Calculation, statistical analysis, visualisation and comparison of Radium equivalent concertation and I-indexes of imported sample information to screen materials

- To prepare the online version of By-BM database

\section{Materials and methods}

\subsection{Restrictions set on the data that was used for the database}

Generally, the reported activity concentrations of investigated samples are presented as a range with a mean value which does not allow further statistical analysis by the readers. The new database will only contain measurement information on individual samples, and specific restrictions were set to obtain a systematic dataset suitable for statistical analysis:

- The data was imported only if it was obtained by gamma spectrometry

- Published data on individual samples was used in the database only if the Ra226, Th-232 and K-40 contents was presented separately for each and every sample

- Average results of certain materials were used only if the investigated material originated from the same site, e.g. quarries, mines, reservoirs. In the case of commercial building materials, the brand and the type of the samples had to be explicitly mentioned in the reference before the data was included. Furthermore, the range of the data was also checked, and the mean was used only if the minimum and maximum values were within $20 \%$ of the mean

- In several cases, instead of the Ra-226, the U-238 activity concentration values were reported in publications. In those cases, the reported data was imported into the database only if the results were obtained from the Rn-222 progenies (Bi-214, Pb-214) to avoid the disequilibrium between $\mathrm{U}-238$ and Ra-226

\subsection{Classification of materials with commonly used indexes}

\subsubsection{Radium equivalent index}

The radium equivalent index $[21]\left(\mathrm{Ra}_{\mathrm{eq}}\right)$ is one of the most frequently used index calculation methods to classify materials on the basis their Ra-226, Th-232 and K-40 content. Owing to the different gamma-ray emission of the terrestrial isotopes and their decay chain their dose rate contribution differs. The calculation of $\mathrm{Ra}_{\text {eq }}$ assumes that $259 \mathrm{~Bq} / \mathrm{kg}$ of Th-232 and $4810 \mathrm{~Bq} / \mathrm{kg}$ of $\mathrm{K}-40$ causes a dose rate equivalent to $370 \mathrm{~Bq} / \mathrm{kg}$ of $\mathrm{Ra}-226$. As a result of the weighting of the dose contribution of Th-232 and K-40 isotopes, the $\mathrm{Ra}_{\mathrm{eq}}$ concentration can be calculated with the following formula [21]:

$R a_{e q}=A_{R a-226}+1.43 A_{T h-232}+0.077 A_{K-40}$

where $A_{\text {Ra-226 }}, A_{T h-232}$, and $A_{K-40}$ are the activity concentration of Ra-226, Th-232, and $\mathrm{K}-40$, respectively. In the case of construction materials, the $\mathrm{Ra}_{\mathrm{eq}}$ concentration has to be lower than $370 \mathrm{~Bq} / \mathrm{kg}$ to keep the annual external dose below $1.5 \mathrm{mSv} / \mathrm{y}$ [22]. In literature, publications are available which present differentiated application cate-

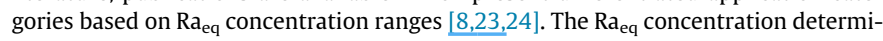
nes the type of allowed application. 
2.2.2. Calculation of dose rate, absorbed dose rate and annual dose excess based on RP112

A dose rate calculation method is presented in RP-112 [25] for calculating dose due to external gamma radiation from building materials. This method by the approach of Markkanen [26] is also widely used. According to the presented model described in RP-112, a reference room (dimensions of the standard room $4 \mathrm{~m} \times 5 \mathrm{~m} \times 2.8 \mathrm{~m}$ ) with concrete walls (all structure such as a floor, ceiling, and walls, with $20 \mathrm{~cm}$ thickness and $2350 \mathrm{~kg} / \mathrm{m}^{3}$ density) can be used to estimate the indoor dose rate. The indoor dose rate can be obtained with the following formula:

$\dot{D}_{\text {indoor }}=f_{R a-226} \cdot A_{R a-226}+f_{T h-232} \cdot A_{T h-232}+f_{K-40} \cdot A_{K-40}$

where $A_{\text {Ra-226 }}, A_{T h-232}$, and $A_{K-40}$ are the activity concentration $[\mathrm{Bq} / \mathrm{kg}]$ of Ra-226, Th232 , and $\mathrm{K}-40$, respectively. The values of conversion factors $[(\mathrm{nGy} / \mathrm{h}) /(\mathrm{Bq} / \mathrm{kg})]$ of Ra$226\left(\mathrm{f}_{\mathrm{Ra}-226}\right), \mathrm{Th}-232\left(\mathrm{f}_{\mathrm{Th}-232}\right)$ and $\mathrm{K}-40\left(\mathrm{f}_{\mathrm{K}-40}\right)$ are $0.92,1.1$ and 0.08 , respectively.To determine the annual dose excess $[\mathrm{mSv} / \mathrm{y}]$ of residents, the natural background gamma dose rate $\left(\dot{D}_{\text {background }}=50 \mathrm{nGy} / \mathrm{h}\right)$, the indoor spent time $(\mathrm{t}=0.8 \times 365$ day $\times 24 \mathrm{~h}$, where 0.8 is the occupancy factor) and the dose conversion factor $(\mathrm{F}=0.7 \mathrm{~Sv} / \mathrm{Bq})$ should be taken into consideration. The annual effective dose excess $[\mathrm{mSv} / \mathrm{y}]$ can then be calculated with the following formula [26]:

$E_{\text {annual }}=\left(\dot{D}_{\text {indoor }}-\dot{D}_{\text {background }}\right) \times t \times F \times 10^{-6}$

\subsubsection{I-index}

Generally, to limit gamma exposure originated from building materials the widely used I-index - also defined in RP-112 [25] - is applied. The calculation method for the I-index is based on the model of Markkanen [26]. According to this model, a $1.0 \mathrm{mSv}$ dose excess can be the result of exposure to respectively $276 \mathrm{~Bq}$ $\mathrm{kg} \mathrm{Ra}-226,231 \mathrm{~Bq} / \mathrm{kg}$ Th-232 and $3176 \mathrm{~Bq} / \mathrm{kg}$ of K-40. In the final formula of I-index, the values computed above are rounded to the nearest full $100 \mathrm{~Bq} / \mathrm{kg}$ (Ra-226 and $\mathrm{Th}-232)$ or $1000 \mathrm{~Bq} / \mathrm{kg}(\mathrm{K}-40)$ [25].

$I=\frac{C_{R a-226}}{300 B q / k g}+\frac{C_{T h-232}}{200 B q / k g}+\frac{C_{K-40}}{3000 B q / k g}$

where $\mathrm{C}_{\mathrm{Ra}-226}, \mathrm{C}_{\mathrm{Th}-232}, \mathrm{C}_{\mathrm{K}-40}$ are the Ra-226, Th-232 and K-40 activity concentrations expressed in $\mathrm{Bq} / \mathrm{kg}$.

The I-index value of 1.0 can be used as a conservative screening tool for identifying building materials that during their use would cause doses exceeding the reference level ( $1 \mathrm{mSv} / \mathrm{y}$ excess in addition to outdoor exposure) in the case of bulk amount inbuilt [27]. In the European Union to control the gamma-exposure originating from building materials, the I-index is recommended for the member states to screen a defined list of materials when they are used in buildings [27]. Building products with an index larger than one the real criterion, exposure relative to the reference level $(<1 \mathrm{mSv} / \mathrm{y})$, need to be verified and other parameters such as the density, the thickness of the material and their inbuilt (bulk amount or superficial) should be taken into account $[28,27]$.

\section{Results and discussion}

\subsection{Database content information}

The current version of the By-BM database (date: 20/12/2016) contains individual data about Ra-226, Th-232, K-40 activity concentration of 28 different materials ( 21 construction materials, 7 by-products, Table 1). Altogether, information about 431 byproducts and 1095 construction materials and raw materials was collected from 48 countries.

The worldwide distribution and the number of data are illustrated in Fig. 1.

\subsection{Distribution of natural radionuclide content of construction materials and by-products}

The distribution of the Ra-226, Th-232, K-40 activity concentration in the event of construction materials and by-products is illustrated in Fig. 2 with $50 \mathrm{~Bq} / \mathrm{kg}, 50 \mathrm{~Bq} / \mathrm{kg}$ and $100 \mathrm{~Bq} / \mathrm{kg}$ bin size resolution, respectively (empty bins were not illustrated). In the case of construction materials, the $\mathrm{K}-40$ content was generally higher, while the Ra-226 and Th-232 activity levels were usually lower compared with industrial by-products.

As a result of the data analysis, it was found that in the case of the construction materials the natural isotope content varied widely, more so than for the by-products (Table 2). The obtained
Table 1

Number of collected materials.

\begin{tabular}{|c|c|c|}
\hline Material name & \# & Reference \\
\hline Aggregate & 9 & {$[29-32]$} \\
\hline Brick & 243 & $\begin{array}{l}{[33-38,29,39,24,40-43]} \\
{[30,44-54,30,31,55]}\end{array}$ \\
\hline Cement & 87 & {$[56,57,29,41,43,58,59,47-51,60,61,54,30,31,55,32]$} \\
\hline Ceramics & 94 & {$[62-64,35,29,39,65-67,46,48,30,55]$} \\
\hline OPC concrete & 63 & {$[33,29,39,24,40,68,69,49,70,50,30]$} \\
\hline Gas concrete & 37 & {$[33,24,71,48,50]$} \\
\hline Granite & 297 & {$[64,35,72,73,74,39,75-84]$} \\
\hline Gypsum & 66 & {$[85,35,86,48-50,87,55,32]$} \\
\hline Rock & 175 & $\begin{array}{l}{[29,39,75,48,49,52,31,55]} \\
{[35,66,46,80,50,83,61,65,78,30,59]}\end{array}$ \\
\hline Sand & 19 & {$[61,54,30,31,55,32]$} \\
\hline Asbestos tile & 4 & {$[54,30,31]$} \\
\hline Bottom ash & 59 & {$[33,85,88,24,89-94]$} \\
\hline Fly ash & 145 & {$[85,29,95,91,96,97,89,70,50,98,90,93,94,99,100]$} \\
\hline Manganese clay & 44 & {$[101,102]$} \\
\hline Phosphogypsum & 45 & {$[29,41,103]$} \\
\hline Red mud & 92 & {$[104,105,57]$} \\
\hline Steel slag & 41 & {$[106-108]$} \\
\hline Residue of $\mathrm{TiO}_{2}$ & 5 & {$[65,87]$} \\
\hline
\end{tabular}

data was compared with world average radionuclide content of building materials $(500 \mathrm{~Bq} / \mathrm{kg}, 50 \mathrm{~Bq} / \mathrm{kg}, 50 \mathrm{~Bq} / \mathrm{kg}$ of $\mathrm{K}-40, \mathrm{Ra}-226$ and Th-232, respectively) [13]. But the average values for the Ra226, Th-232 and K-40 content of reported by-products were respectively $2.00,2.11$ and 0.48 times higher when compared to the construction materials. The median is not skewed so much by outliers than the average values. The obtained mean values of the Ra-226, Th-232 and K-40 activity concentrations were respectively $1.97,1.24$ and 0.53 times higher in the case of by-products. The box-and-whisker plot diagram is widely used to get visual information about the distribution of the data. In addition to the median, the lower ( 25 percentile) quartile, the upper (75 percentile) quartile and $1.5 \times \mathrm{IQR}$ (Inter-Quartile Range) are also shown to detect the outliers of the data set [109]. However, the obtained diagrams show a rough distribution of the data; further data mining could change and sophisticate the received picture about the natural radionuclide content in construction materials and also in by-products.

Approximately, 34\% of the collected activity concentration values for construction materials were over $50 \mathrm{~Bq} / \mathrm{kg} \mathrm{Ra}-226$, while in the case of the by-products, $83.5 \%$ of the samples showed a Ra-226 activity concentration higher than $50 \mathrm{~Bq} / \mathrm{kg}$. The Th-232 activity concentration was over $50 \mathrm{~Bq} / \mathrm{kg}$ for $38.1 \%$ of the construction materials and $61.5 \%$ of the by-products. Generally, the K-40 content in construction materials was higher than in the byproducts: altogether, $45.3 \%$ of the construction materials and $16.2 \%$ of the by-products demonstrated an activity concentration above $500 \mathrm{~Bq} / \mathrm{kg} \mathrm{K}-40$. Although the activity concentration for K40 is higher in the event of construction materials the formed gamma dose, as a result of their bulk amount inbuilt mainly originates from Ra-226 and Th-232 [25]. Owing to this fact, it can be stated that particularly the elevated levels of Ra-226 and Th-232 in by-products can pose an increased risk to residents and that therefore radiological screening of by-products is required before they are used for the production of construction or building materials.

\subsection{Results of commonly used indexes}

\subsubsection{Radium equivalent index}

In Figs. 3. and 4. detailed information is illustrated about the $\mathrm{Ra}_{\mathrm{eq}}$ distribution of analysed data. It is evident from Table 3 and Fig. 3 that by-products are available for reuse can pose elevated radiological risks when they are included in as building materials. 


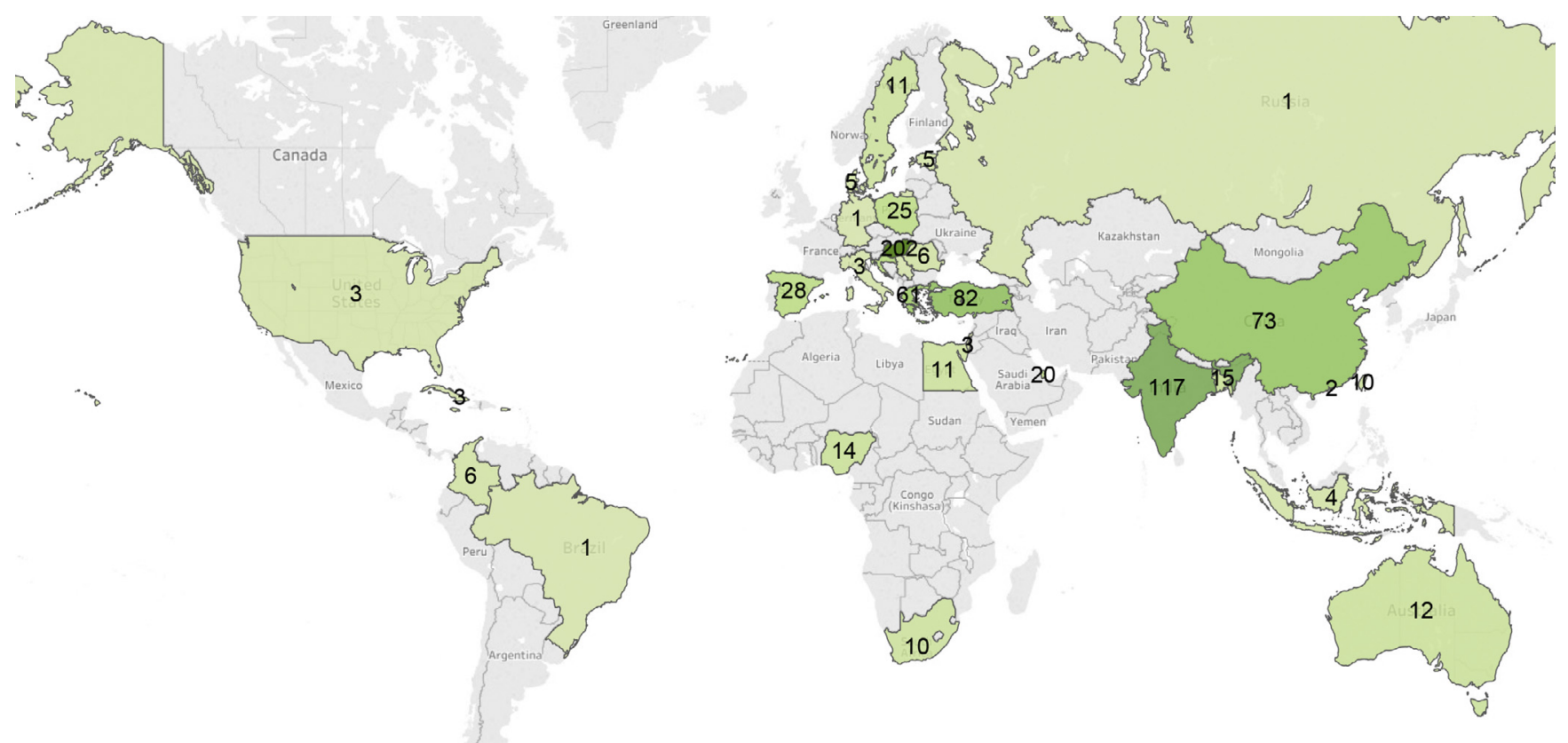

Count of Number of Records

Fig. 1. The global distribution and the number of gathered data.

Owing to that fact, it is evident that the screening before their reuse is clearly required. Even by-products of the same plant can be quite heterogeneous [104] owing to variations in the origin of the raw materials and the applied industrial processing method. Using the classification method proposed by $[8,24,23]$, the population of the different categories for the $\mathrm{Ra}_{\mathrm{eq}}$ activity concentrations extracted from the By-BM database is shown in Fig. 4.

The accepted $\mathrm{Ra}_{\mathrm{eq}}$ ranges proposed for differentiated categories of application are the following:

I. For building residential houses: $\mathrm{Ra}_{\mathrm{eq}}<370 \mathrm{~Bq} / \mathrm{kg}$

II. For industrial use: $370<\mathrm{Ra}_{\mathrm{eq}}<740 \mathrm{~Bq} / \mathrm{kg}$

III. For roads and railways: $740<\mathrm{Ra}_{\mathrm{eq}}<2200 \mathrm{~Bq} / \mathrm{kg}$

IV. For landfilling: $2200<\mathrm{Ra}_{\mathrm{eq}}<3700 \mathrm{~Bq} / \mathrm{kg}$

V. Forbidden to use for any construction: $\mathrm{Ra}_{\mathrm{eq}}>3700 \mathrm{~Bq} / \mathrm{kg}$

The $\mathrm{Ra}_{\mathrm{eq}}$ describes the gamma dose contribution of investigated materials in a more straightforward way than the plots for individual Ra-226, Th-232, K-40 activity concentrations. In Table 3. some key statistical features that were extracted from the calculated $\mathrm{Ra}_{\mathrm{eq}}$ concentration values are summarised.

For construction materials, $89.7 \%$ can be found in category I. under $370 \mathrm{~Bq} / \mathrm{kg} \mathrm{Ra}$ eq. In the higher categories, a limited amount of granite and rock samples were found while for the other considered construction materials over $95 \%$ of the construction materials were found under Category I. In total, only $28.3 \%$ of the granite and only $11.4 \%$ of the rock were found under categories II, III, IV and V. On the contrary, numerous by-product samples - except manganese clay - needed to be categorised in Category II, III or IV.

For red mud the main fraction, 63\% was found under category II, dedicated to industrial construction, while for phosphogypsum this was $44.4 \%$ and for steel slag $24.4 \%$. In Category III, between 740 and $2200 \mathrm{~Bq} / \mathrm{kg} \mathrm{Ra}$ eq, a significant amount of records related to by-products was found, especially $\mathrm{TiO}_{2}$ sludge (60\%), red mud (33.7\%), bottom ash (11.9\%) and fly ash (9\%), which would be eligible only for road construction. Only a very limited amount of data ( $5.1 \%$ of bottom ash and $1.1 \%$ of red mud) was found between 2200 and $3700 \mathrm{~Bq} / \mathrm{kg} \mathrm{Ra}$ eq (category IV) which indicates that the materi- als are still acceptable for landfilling. Above $3700 \mathrm{~Bq} / \mathrm{kg} \mathrm{Ra}$ eq, only three Egyptian granites (1.0\% of total granite samples) were found, which cannot be used for any construction applications.

\subsubsection{Annual effective dose excess based on RP-112}

The Absorbed Gamma Dose Rate (AGDR) and the Annual Gamma Dose Excess (AGDE) based on the dose calculation method presented in RP-112 [25] are shown in Fig. 5. It was found that 25\% of the construction materials could cause less AGDR than the $50 \mathrm{nGy} / \mathrm{h}$ value (Fig. 5). It means that the bulk incorporation would result in a lower AGDR relative to the world average background radiation. From the obtained AGDR values the AGDE were calculated. It can be clearly seen that in the case of construction materials more than $84.4 \%$ of the reported data was lower than the reference level with $1.0 \mathrm{mSv}$ AGDE, while in the event of byproducts only $41.7 \%$ was in a lower dose excess assuming bulk incorporation.

\subsubsection{I-index}

Regarding the I-index, it should be noted that the I-index can be used only for real building materials such as concrete and ceramics (but not for cement). The calculation of I-index of any raw (sand, aggregate), construction materials (cement, lime) or by-products would imply that $100 \%$ of these materials are used as building materials. Of course, this not realistic for most construction materials where only a fraction of certain by-products can be included, but it provides an opportunity for their screening or prediction [6] of the I-index of the final product. If needed, a dilution factor could be used for a given application to achieve more realistic screening (Fig. 7). The main parameters obtained after the statistical analysis of the calculated I-index values, related to construction materials and by-products, are presented in Table 4.

The calculated I-indexes (for the by-products the assumption was made that $100 \%$ of the by-products used as a building material) are shown in Fig. 6. As it was expected from the radionuclide distribution and calculated $\mathrm{Ra}_{\mathrm{eq}}$ in the event of the by-product, the calculated I-index values were significantly higher than construction materials. In Fig. 6 it can be clearly seen that all the by- 


\section{Distribution of natural radionuclide concentration in construction materials}

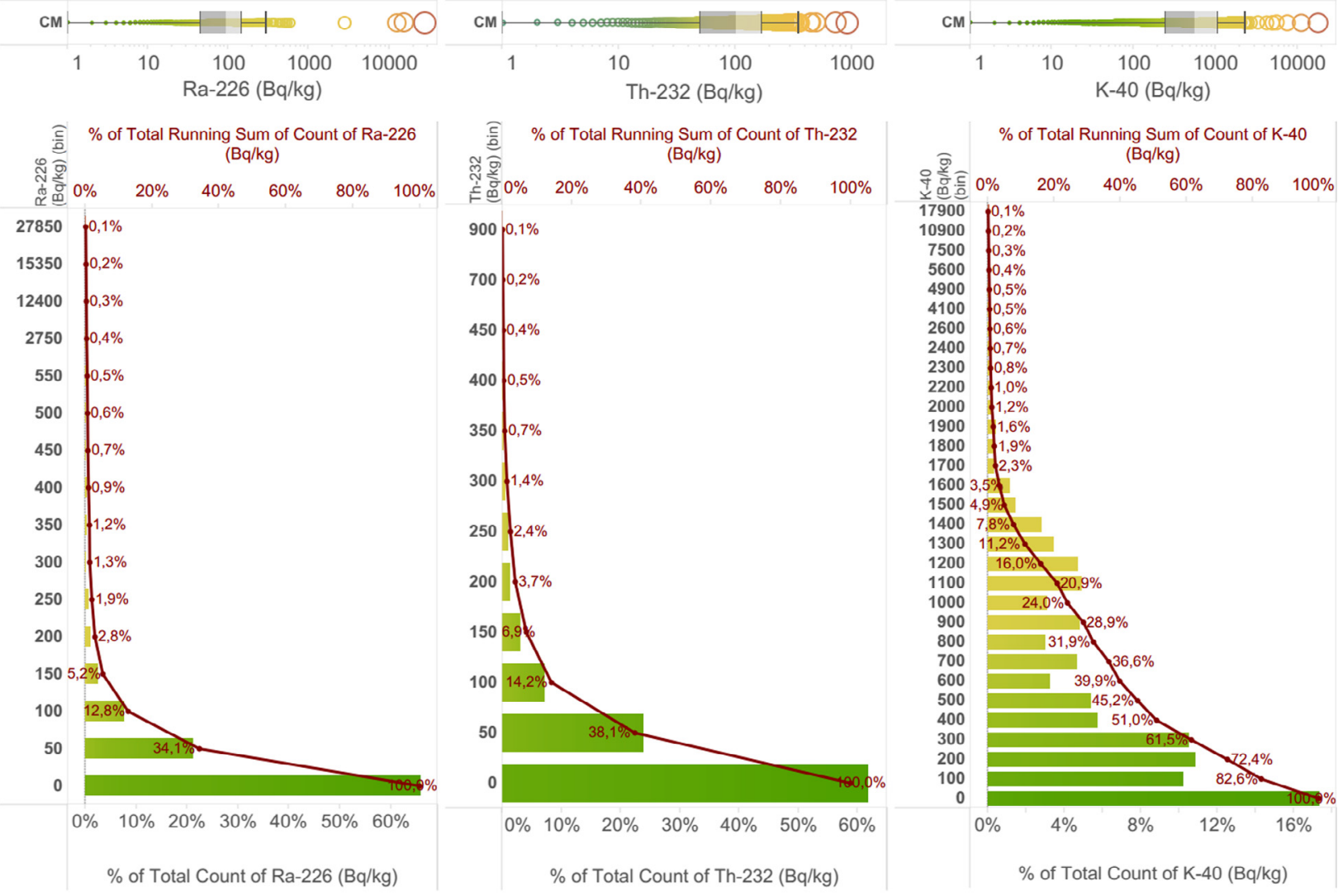

Distribution of natural radionuclide concentration in by-products
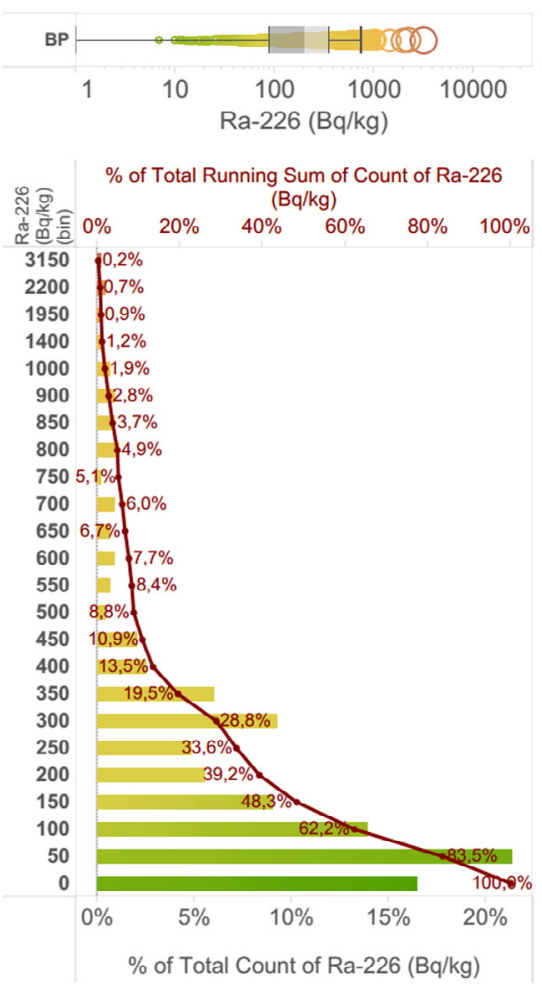

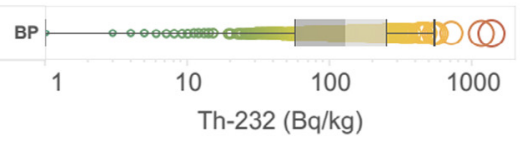

$\%$ of Total Running Sum of Count of Th-232

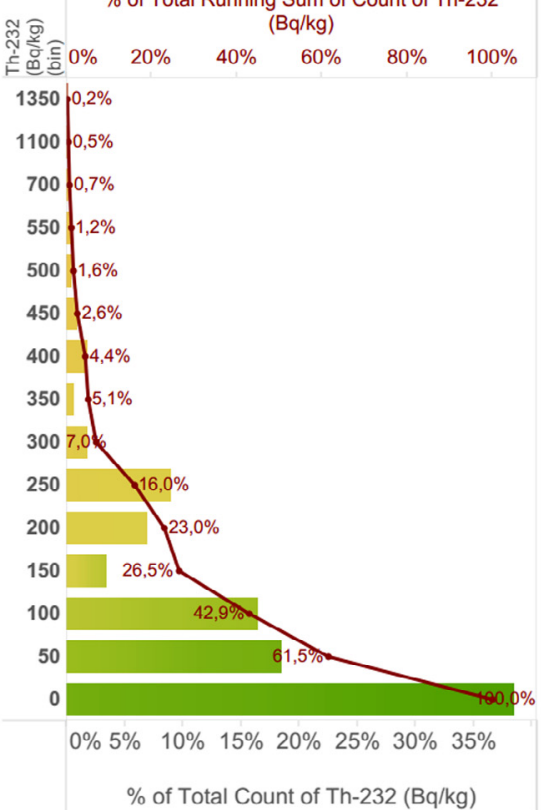

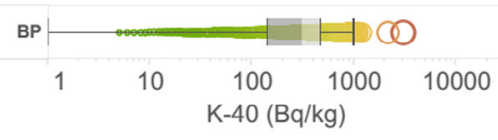

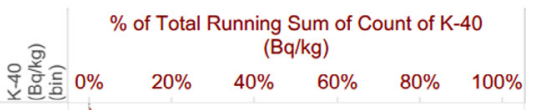
$3000 \quad 0,2 \%$

$2900 \quad 0,5 \%$

$2100-0,7 \%$

$1100 \quad 1,4 \%$

$1000\{2,1 \%$

$900 \quad 3,9 \%$

$8005,3 \%$

$7008,1 \%$

600

$500 \quad 16,2 \%$

$400 \quad 27,4 \%$

100

0

$\begin{array}{llllllll}0 \% & 5 \% & 10 \% & 15 \% & 20 \% & 25 \% & 30 \%\end{array}$

$\%$ of Total Count of K-40 (Bq/kg)

Fig. 2. Distribution of Ra-226, Th-232, and K-40 activity concentration of construction materials and by-products. 
Table 2

Main statistical properties of analysed data.

\begin{tabular}{|c|c|c|c|c|c|c|}
\hline \multirow[b]{2}{*}{ Statistical properties } & \multicolumn{3}{|c|}{ Construction materials } & \multicolumn{3}{|c|}{ By-products } \\
\hline & Ra-226 & Th-232 & $\mathrm{K}-40$ & Ra-226 & Th-232 & $\mathrm{K}-40$ \\
\hline $\operatorname{Min}[\mathrm{Bq} / \mathrm{kg}]$ & 1 & 1 & 1 & 10 & 1 & 5 \\
\hline $\operatorname{Max}[\mathrm{Bq} / \mathrm{kg}]$ & 27851 & 906 & 17922 & 3152 & 1350 & 3001 \\
\hline Average $[\mathrm{Bq} / \mathrm{kg}]$ & 112 & 61 & 668 & 224 & 129 & 318 \\
\hline Q1 Lower quartile $[\mathrm{Bq} / \mathrm{kg}]$ & 47 & 50 & 251 & 84 & 57 & 142 \\
\hline Median $[\mathrm{Bq} / \mathrm{kg}]$ & 95 & 101 & 576 & 187 & 125 & 307 \\
\hline Q3 Upper quartile [Bq/kg] & 148 & 172 & 1093 & 338 & 250 & 471 \\
\hline Most frequent range $[\mathrm{Bq} / \mathrm{kg}]$ & $0-50$ & $0-50$ & $0-100$ & $50-100$ & $0-50$ & $0-100$ \\
\hline$\%$ of samples in the most frequent range & 65.9 & 61.9 & 17.4 & 32.3 & 38.5 & 33.2 \\
\hline WA in building materials [Bq/kg] [13] & 50 & 50 & 500 & 50 & 50 & 500 \\
\hline$\%$ of samples $>$ WA & 34.1 & 38.1 & 45.3 & 83.5 & 61.5 & 16.2 \\
\hline
\end{tabular}

\section{Construction material Raeq}

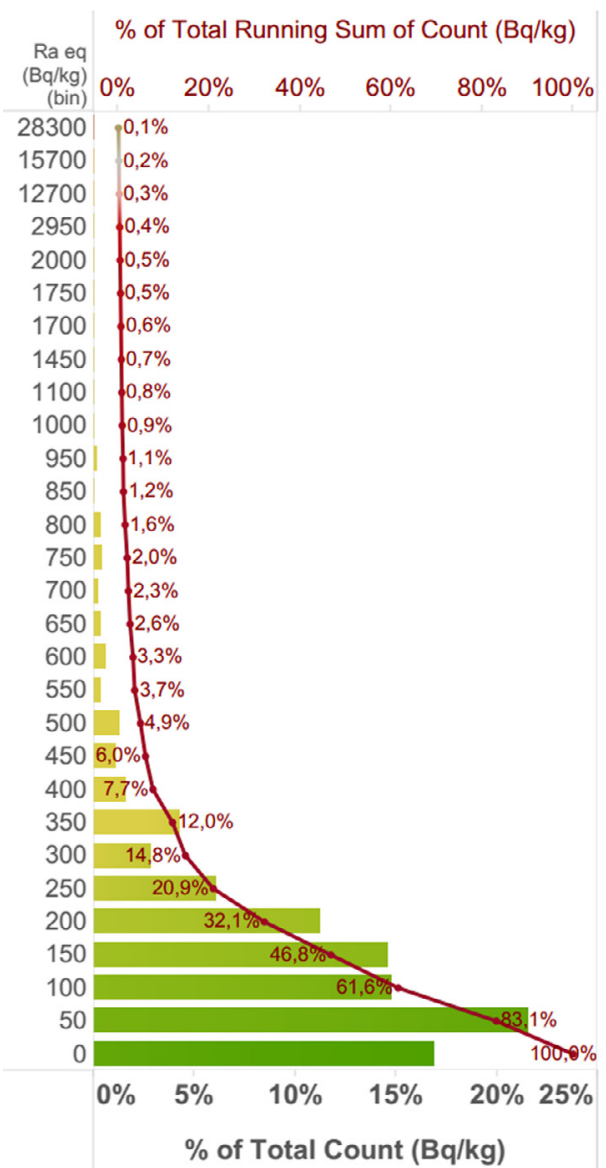

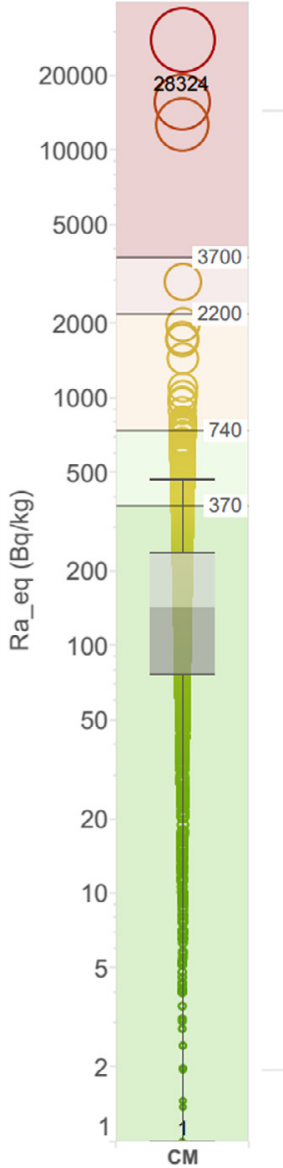

By-product Raeq

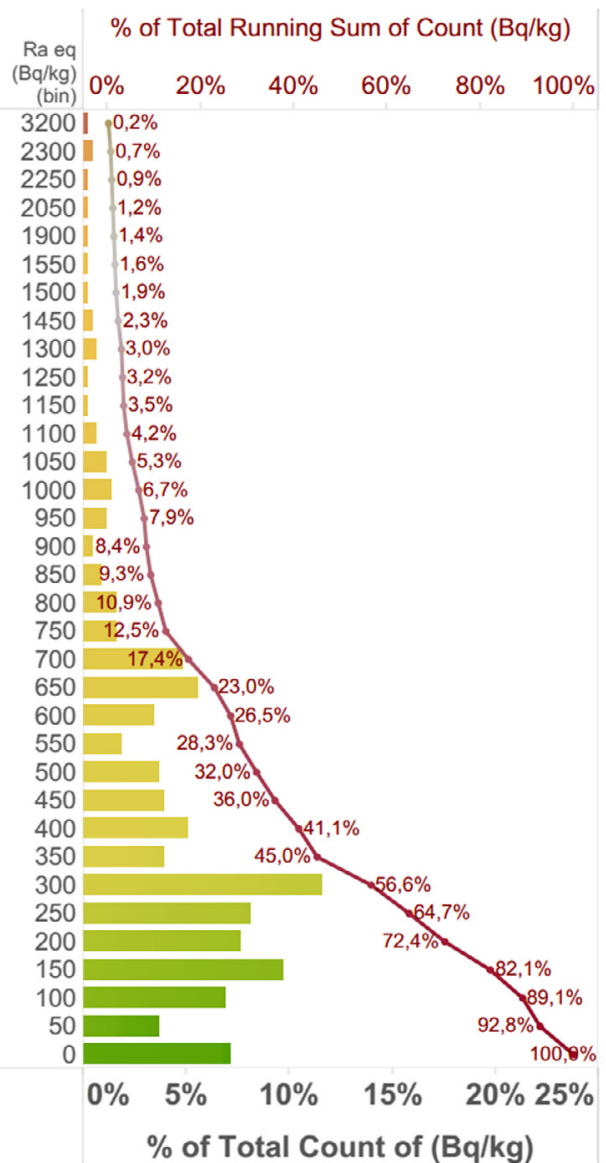

Fig. 3. Distribution of $\mathrm{Ra}_{\mathrm{eq}}$ activity concentration of construction materials and by-products with $50 \mathrm{~Bq} / \mathrm{kg}$ bin size resolution (empty bins were not illustrated).

products, except the manganese clay, can give yield to an I-index higher than 1.0 in numerous cases.

The red mud samples had a higher value than 1.0 for almost all entries; the $\mathrm{TiO}_{2}$ sludge was also greater in the case of $80 \%$ of entries.

3.3.4. Estimation of maximum allowable mixing ratio of by-products in building materials based on I-index

A simple mixing calculation was performed to estimate an allowable mixing ratio for industrial by-products. The calculation was based on the assumption that the other components of the mixture have an activity concentration that corresponds to the world average activity level of building materials $(500 \mathrm{~Bq} / \mathrm{kg}$,
$50 \mathrm{~Bq} / \mathrm{kg}, 50 \mathrm{~Bq} / \mathrm{kg}$ for $\mathrm{K}-40, \mathrm{Ra}-226$ and Th-232, respectively [13]). For the mixing calculation the following equation was used:

$X_{B P \%} \times I_{B P}+X_{W A \%} \times I_{W A}=X_{100 \%} \times I_{\text {max }_{-} 1.0}$

where $\mathrm{X}_{\mathrm{BP} \%} ; \mathrm{X}_{\mathrm{WA} \%}$ and $\mathrm{X}_{100 \%}$ are the ratio in\% of the by-products, other components (aggregates, binders, etc.) of the mixture with world average radionuclide activity concentration (hypothetic value) and the total amount (100\%), respectively. The $I_{B P}, I_{W A}$ are the calculated I-indexes of by-products and the world average radionuclide content. The $\mathrm{I}_{\text {max }_{-} 1.0}$ is 1.0 I-index value used as a upper-level reference for screening. The obtained maximal allowable mixing ratios are illustrated in Fig. 7. Of course, the byproducts with $\mathrm{I}$-index value $\leq 1.0$ can be mixed without any 


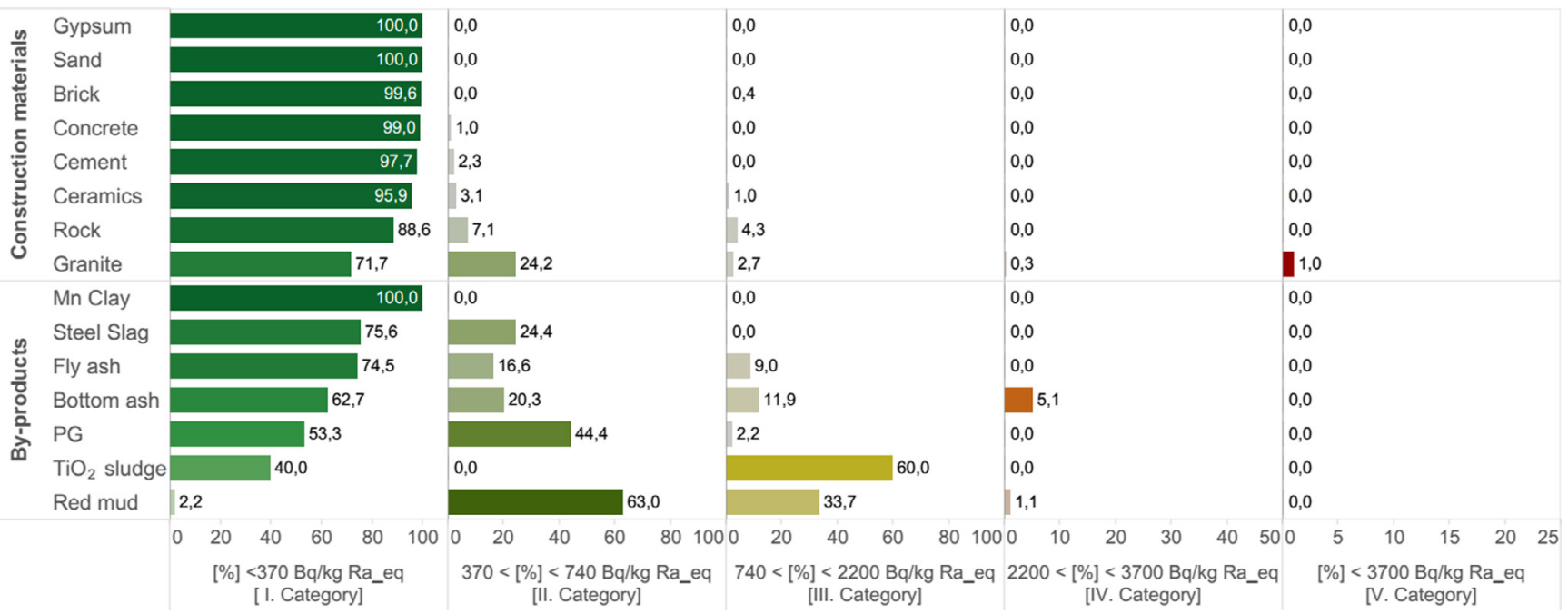

Fig. 4. Distribution of $\mathrm{Ra}_{\mathrm{eq}}$ activity concentration of construction materials and by-products according to classification criteria.

Table 3

Main statistical properties of the calculated $\mathrm{Ra}_{\mathrm{eq}}$ concentration values.

\begin{tabular}{lll}
\hline Statistical properties & $\begin{array}{l}\mathrm{Ra}_{\text {eq }} \text { construction } \\
\text { materials }\end{array}$ & $\begin{array}{l}\mathrm{Ra}_{\text {eq }} \text { by- } \\
\text { products }\end{array}$ \\
\hline Min [Bq/kg] & 1 & 9 \\
Max [Bq/kg] & 28324 & 3215 \\
Average [Bq/kg] & 233 & 434 \\
Q1 Lower quartile [Bq $/ \mathrm{kg}]$ & 77 & 172 \\
Median [Bq $/ \mathrm{kg}]$ & 143 & 334 \\
Q3 Upper quartile [Bq $/ \mathrm{kg}]$ & 236 & 612 \\
Most frequent range [Bq/kg] & $50-100$ & $300-350$ \\
\% of samples in the most frequent & 21.5 & 11.6 \\
$\quad$ range & 10.3 & 42.4 \\
\hline of samples $>370 \mathrm{~Bq} / \mathrm{kg} \mathrm{Ra}$ eq & & \\
\hline
\end{tabular}

restriction, but above that value, the maximum allowable mixing ratio should be calculated.

To draw conclusions regarding the inhomogeneity of the natural radionuclide content of by-products and also about their mixability the weighted average values were also computed with 95\% confidence interval. The width of the intervals depends on the number of the data analyses and also on the inhomogeneity of the samples, but this parameter can be used to facilitate conclusions about the inhomogeneity. The narrowest interval $( \pm 2.5 \%$ width) was found in the case of red mud around its $24.0 \%$ average mixing ratio. Also, a narrow range, only $\pm 4.7 \%$ around its 73 .3\% average was observed related to fly ash. However, the confidence intervals combined with the inhomogeneity of some materials can be roughly estimated to make overall conclusion according to the number of analysed data. As the database increases, a more clear picture will develop about the worldwide distribution of their radionuclide content. According to I-index values of by-products, it can be concluded that generally, the reuse of them as building materials is possible, but only in limited amounts with regular screening. The radionuclide content of recycled by-products cannot be ignored since they can cause increased radiological risk.

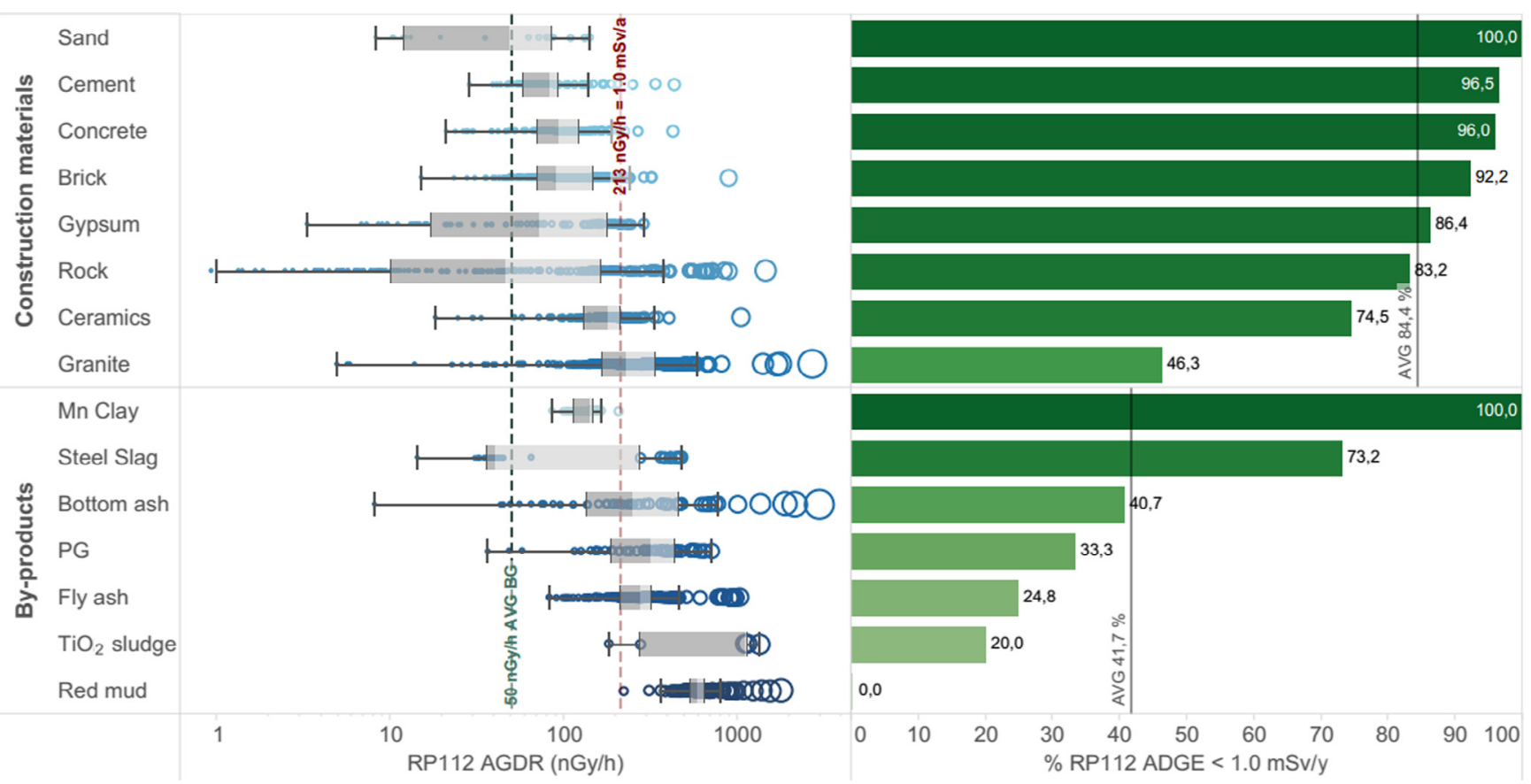

Fig. 5. Absorbed Gamma Dose Rate (AGDR) and Annual Gamma Dose Excess (AGDE) of analysed construction materials and by-products based on RP-112 [25]. 


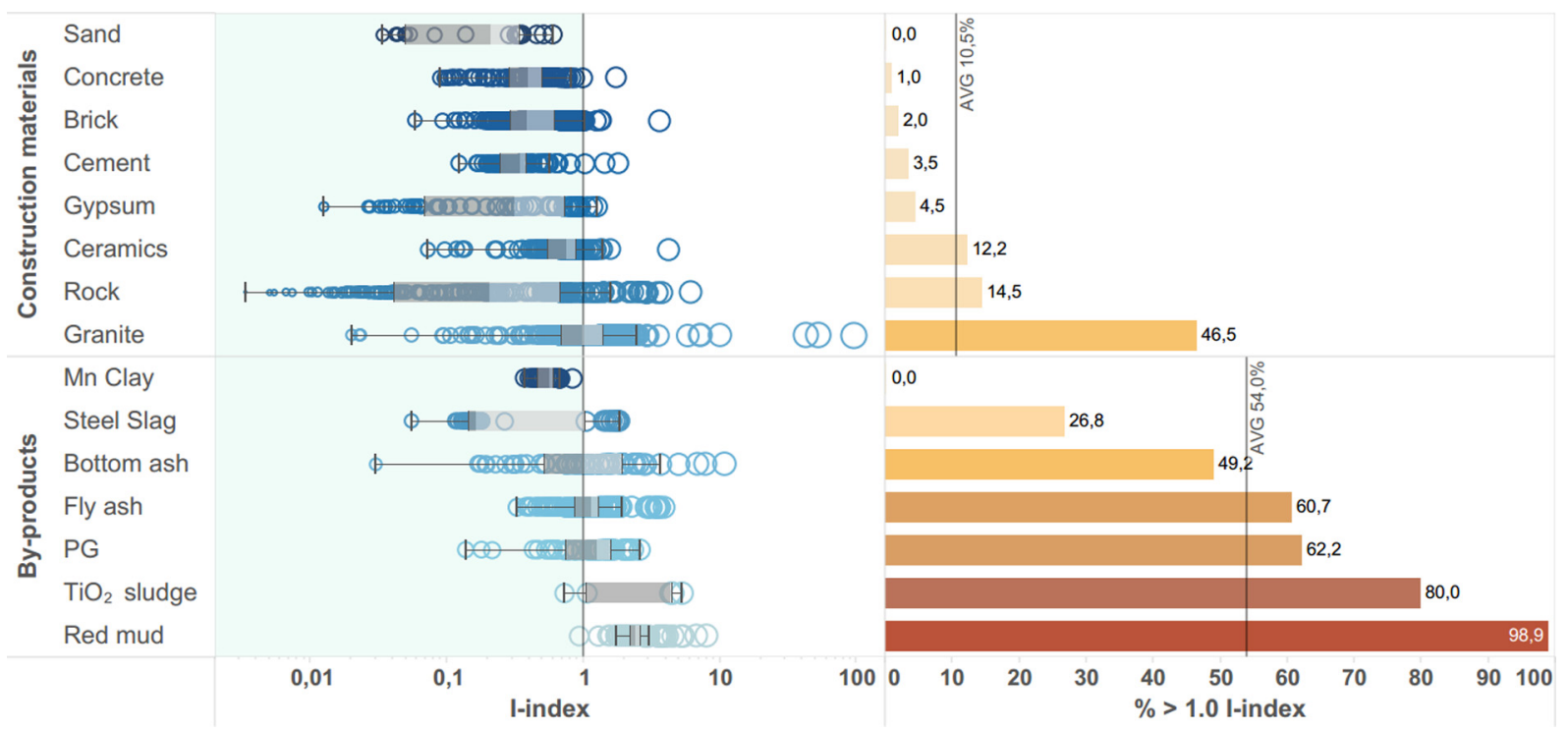

Fig. 6. I-index of analysed construction materials and by-products.

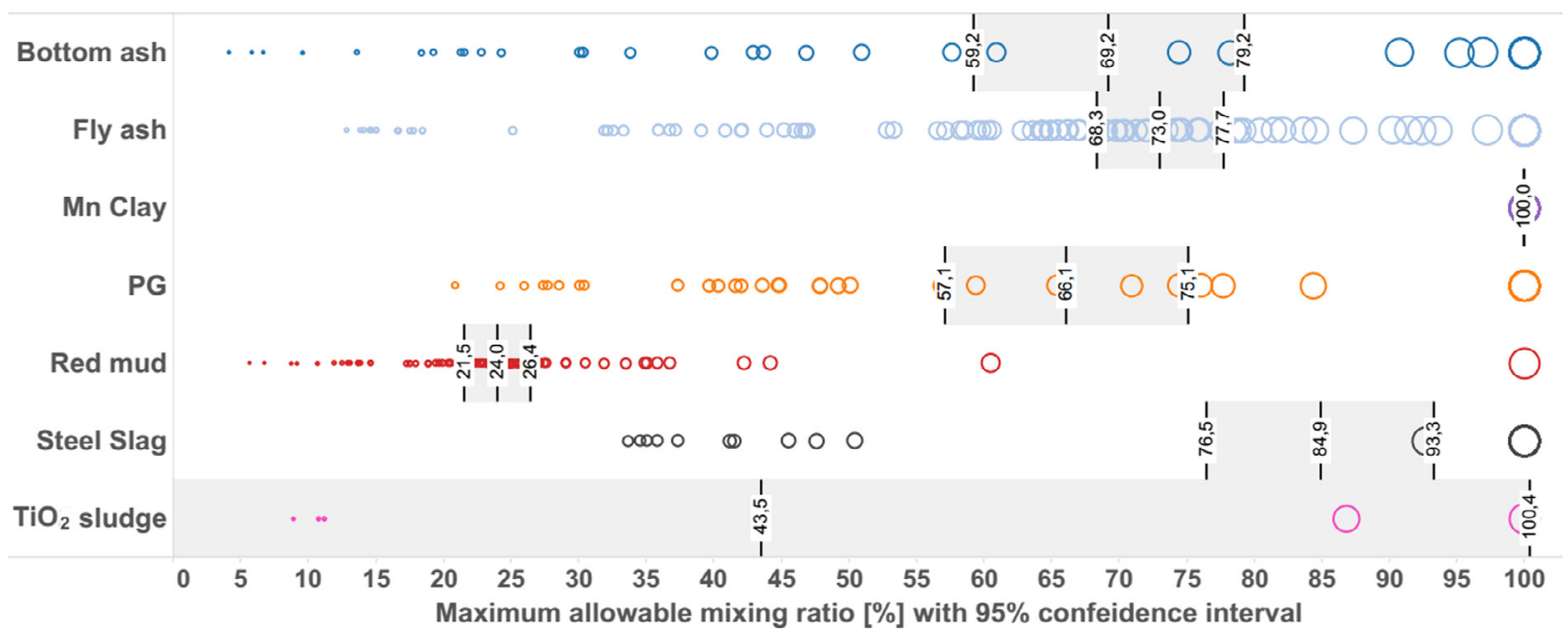

Fig. 7. Maximum allowable mixing ratio of by-products related to world average radionuclide content of building materials [13].

Table 4

Main statistical properties of calculated I-indexes.

\begin{tabular}{lll}
\hline Statistical properties & $\begin{array}{l}\text { I-index of construction } \\
\text { materials }\end{array}$ & $\begin{array}{l}\text { I-index of by- } \\
\text { products }\end{array}$ \\
\hline Min & 0.01 & 0.03 \\
Max & 94.6 & 10.7 \\
Average & 0.84 & 1.50 \\
Q1 Lower quartile & 0.29 & 0.63 \\
Median & 0.56 & 1.18 \\
Q3 Upper quartile & 0.89 & 2.11 \\
\% of samples > 1.0 I- & 17.3 & 58.2 \\
$\quad$ index & & \\
\hline
\end{tabular}

According to EU-BSS [27], the dilution factor has to be determined as the function of the activity concentration of the components $[6,104]$.

The screening of by-products and construction materials can be a practical tool to identify and manage potential material resources which can pose an elevated risk. The bulk amount of these materials included in the design of building products requires more detailed design [57] with e.g. density and thickness characterization as highlighted in EU-BSS [27].

\section{Conclusion}

A large, disparate quantity of data regarding the natural radioactivity is reported in the literature. Generally, this data is presented as ranges or in diagrams which make it less suitable for detailed further statistical analysis. However, there is also data available involving individually reported sample information, and this data was processed for statistical analysis.

As a result of the statistical analysis, it was found that the Ra226, Th-232 and K-40 content of reported recycled by-products were $2.00,2.11$ and 0.48 times higher compared with natural construction materials. It can be concluded that some of the studied by-products can pose elevated radiological risks in cases where they are included as building materials, and therefore screening before their reuse is required. The calculated $\mathrm{Ra}_{\mathrm{eq}}$ and I-indexes are useful tools to classify materials before inclusion in building products. However, these indexes can exemplify the risk of the external exposure better than the activity concentration of Ra226, Th-232, K-40. Other factors (density and thickness) should be taken into consideration when designing building materials that contain such recycled by-products. Furthermore, differentiated 
categories could offer more flexible reuse options depending on the final use. However, the statistical results of current study provide the possibility to make the first rough conclusions about the worldwide radionuclide content of construction materials and industrial by-products, as the database increases this will lead to a clearer picture of the distribution of radionuclides in surveyed materials, which can be obtained with further data mining based on the established unified selection criteria.

\section{Acknowledgements}

The project leading to this application has received funding from the European Union's Horizon 2020 research and innovation programme under the Marie Sklodowska-Curie grant agreement No 701932. R. Doherty's time was also supported by the European Union's Horizon 2020 research and innovation programme under the Marie Sklodowska-Curie grant agreement No 643087. The authors would also like to acknowledge networking support by the COST Action TU1301. www.norm4building.org.

\section{References}

[1] European Commisssion, Directive 2008/98/EC of the European Parliament and of the Council of 19 November 2008 on waste and repealing certain directives, Off. J. Eur. Union. L13 (2008) 3-30. doi:2008/98/EC.; 32008L0098.

[2] Ellen MacArthur Foundation, Growth within: a circular economy vision for a competitive Europe, Ellen MacArthur Found. (2015). https://www. ellenmacarthurfoundation.org/assets/downloads/publications/ EllenMacArthurFoundation_Growth-Within_July15.pdf (accessed December 16, 2016).

[3] D. Bondar, E. Coakley, Use of gypsum and CKD to enhance early age strength of High Volume Fly Ash (HVFA) pastes, Constr. Build. Mater. 71 (2014) 93108, http://dx.doi.org/10.1016/i.conbuildmat.2014.08.015.

[4] R. Vinai, A. Rafeet, M. Soutsos, W. Sha, The role of water content and paste proportion on physico-mechanical properties of alkali activated fly ash GGBS concrete, J. Sustain. Metall. 2 (2016) 51-61, http://dx.doi.org/10.1007/ s40831-015-0032-6.

[5] J. Davidovits, Geopolymer Chemistry \& Applications, 4th ed., Institut Géopolymère, Saint-Quentin, 2015. https://www.geopolymer.org/fichiers pdf/geopolymer-book-chapter1.pdf.

[6] I. Ignjatović, Z. Sas, J. Dragaš, J. Somlai, T. Kovacs, Radiological and material characterization of high volume fly ash concrete, J. Environ. Radioact. 168 (2017) 38-45, http://dx.doi.org/10.1016/j.jenvrad.2016.06.021.

[7] C. Nuccetelli, R. Trevisi, I. Ignjatović, J. Dragaš, Alkali-activated concrete with Serbian fly ash and its radiological impact, J. Environ. Radioact. 168 (2017) 30-37, http://dx.doi.org/10.1016/j.jenvrad.2016.09.002.

[8] J. Somlai, B. Kanyar, R. Bodnar, C. Nemeth, Z. Lendvai, Radiation dose contribution from coal-slags used as structural building material, J. Radioanal Nucl. Chem. Artic. 207 (1996) 437-443, http://dx.doi.org/10.1007/ BF02071248.

[9] B. Mazzilli, C. Saueia, Radiological implications of using phosphogypsum as a building material in Brazil, Radiat. Prot. Dosimetry. 86 (1999) 63-67. http:// rpd.oxfordjournals.org/content/86/1/63.abstract.

[10] İ. Yüksel, A review of steel slag usage in construction industry for sustainable development, Environ. Dev. Sustain. (2016), http://dx.doi.org/10.1007/ s10668-016-9759-x. In press.

[11] G. Xhixha, A. Ahmeti, G.P. Bezzon, M. Bitri, C. Broggini, G.P. Buso, A. Caciolli, I. Callegari, F. Cfarku, T. Colonna, G. Fiorentini, E. Guastaldi, F. Mantovani, G. Massa, R. Menegazzo, L. Mou, D. Prifti, C. Rossi Alvarez, D.S. Kuqi, M. Shyti, L. Tushe, M. Xhixha Kaçeli, A. Zyfi, First characterisation of natural radioactivity in building materials manufactured in Albania, Radiat. Prot. Dosimetry. 155 (2013) 217-223, http://dx.doi.org/10.1093/rpd/ncs334.

[12] United Nations Scientific Committee on the Effects of Atomic Radiation, ANNEX B: Exposures of the public and workers from various sources of radiation, UNSCEAR 2008 Report to the general assembly with scientific annexes, United Nations, New York, 2008, p. 2010.

[13] United Nations Scientific Committee on the Effects of Atomic Radiation, ANNEX A Exposures from natural sources of radiation, UNSCEAR 1993 Report to the general assembly, with scientific annexes, United Nations, New York 1993, p. 1993.

[14] The International Commission on Radiological Protection, Annals of the ICRP, Publication 103, The 2007 recommendations of the International Commission on Radiological Protection, Ann. ICRP 37 (2007) (2007) 1-332, http://dx.doi. org/10.1016/j.icrp.2007.10.003.

[15] World Health Organization, WHO Handbook on indoor radon: a public health perspective, Geneva (2009), http://dx.doi.org/10.1080/00207230903556771.

[16] M. Soutsos, A.P. Boyle, R. Vinai, A. Hadjierakleous, S.J. Barnett, Factors influencing the compressive strength of fly ash based geopolymers, Constr.
Build. Mater. $110 \quad$ (2016) 355-368, http://dx.doi.org/10.1016/ j.conbuildmat.2015.11.045.

[17] T.A. Aiken, W. Sha, J. Kwasny, M.N. Soutsos, Resistance of geopolymer and portland cement based systems to silage effluent attack, Cem. Concr. Res. 92 (2017) 56-65, http://dx.doi.org/10.1016/i.cemconres.2016.11.015.

[18] COST TU1301, NORM4Building database, (2016). http://norm4building.org/ (accessed December 20, 2016).

[19] National Institute of Radiological Sciences, NIRS NORM Database, (n.d.). http://www.nirs.qst.go.jp/db/anzendb/NORMDB/ENG/1_yougosyuu.php (accessed December 20, 2016).

[20] R. Trevisi, S. Risica, M. D’Alessandro, D. Paradiso, C. Nuccetelli, Natural radioactivity in building materials in the European Union: a database and an estimate of radiological significance, J. Environ. Radioact. 105 (2012) 11-20, http://dx.doi.org/10.1016/j.jenvrad.2011.10.001.

[21] J. Beretka, P.J. Matthew, Natural radioactivity of Australian building materials, industrial wastes and by-products, Health Phys. 48 (1985) 87-95. http:// www.ncbi.nlm.nih.gov/pubmed/3967976.

[22] Group Experts of the OECD Nuclear Energy Agency, OECD, Exposure to Radiation From the Natural Radioactivity in Building Materials, OECD (Organization for Economic Cooperation and Development), Paris, 1979. https://www.oecd-nea.org/rp/reports/1979/exposure-to-radiation-1979.pdf.

[23] Z. Szabó, P. Völgyesi, H.É. Nagy, C. Szabó, Z. Kis, O. Csorba, Radioactivity of natural and artificial building materials - a comparative study, J. Environ. Radioact. 118 (2013) 64-74, http://dx.doi.org/10.1016/j.jenvrad.2012.11.008.

[24] P. Volgyesi, Environment geochemical and radiometric study of building material and attic dust samples affected by industrial activity in Hungary, Eötvös Loránd University, 2015. http://teo.elte.hu/minosites/ertekezes2015/ volgyesi_p.pdf.

[25] European Commission, Radiological Protection Principles Concerning the Natural Radioactivity of Building Materials - RP-112, European Comission, Luxemburg, 1999. https://ec.europa.eu/energy/sites/ener/files/documents/ 112.pdf.

[26] M. Markkanen, Radiation dose assessments for materials with elevated natural radioactivity, STUK-B-STO, Finnish Centre for Radiation and Nuclear Safety, Helsinki, 1995. http://www.iaea.org/inis/collection/ NCLCollectionStore/_Public/28/021/28021209.pdf.

[27] Council of the European Union, Council Directive 2013/59/Euratom, 2013. doi:10.3000/19770677.L_2013.124.eng.

[28] C. Nuccetelli, F. Leonardi, R. Trevisi, A new accurate and flexible index to assess the contribution of building materials to indoor gamma exposure, J. Environ. $\quad$ Radioact. 143 (2015) 70-75, http://dx.doi.org/10.1016/ j.jenvrad.2015.02.011.

[29] K. Kovler, G. Haquin, V. Manasherov, E. Ne'Eman, N. Lavi, Natural radionuclides in building materials available in Israel, Build. Environ. 37 (2002) 531-537, http://dx.doi.org/10.1016/S0360-1323(01)00048-8.

[30] P. Hayumbu, M.B. Zaman, N.C.H. Lubaba, S.S. Munsanje, D. Muleya, Natural radioactivity in Zambian building materials collected from Lusaka, I. Radioanal. Nucl. Chem. Lett. 199 (1995) 229-238, http://dx.doi.org/10.1007/ BF02162371.

[31] L. Xinwei, Natural radioactivity in some building materials of Xi'an, China, Radiat. Meas. $40 \quad$ (2005) 94-97, http://dx.doi.org/10.1016/j. radmeas.2005.01.003.

[32] M.A. Kobeissi, O. El Samad, K. Zahraman, S. Milky, F. Bahsoun, K.M. Abumurad, Natural radioactivity measurements in building materials in Southern Lebanon, J. Environ. Radioact. 99 (2008) 1279-1288, http://dx.doi. org/10.1016/j.jenvrad.2008.03.007.

[33] Z. Szabó, P. Völgyesi, H.É. Nagy, C. Szabó, Z. Kis, O. Csorba, Radioactivity of natural and artificial building materials - a comparative study, J. Environ. Radioact. 118 (2013) 64-74, http://dx.doi.org/10.1016/j.jenvrad.2012.11.008.

[34] Z. Sas, J. Somlai, J. Jonas, G. Szeiler, T. Kovacs, C. Gyongyosi, T. Sydo, Radiological survey of Hungarian clays; radon emanation and exhalation influential effect of sample and internal structure conditions, Rom. Reports Phys. 58 (2013). https://www.nipne.ro/rjp/2013_58_Suppl/0243_0250.pdf.

[35] D. Krstić, D. Nikezić, N. Stevanović, D. Vučić, Radioactivity of some domestic and imported building materials from South Eastern Europe, Radiat. Meas. 42 (2007) 1731-1736, http://dx.doi.org/10.1016/j.radmeas.2007.09.001.

[36] R. Hewamanna, C.S. Sumithrarachchi, P. Mahawatte, H.L.C. Nanayakkara, H.C. Ratnayake, Natural radioactivity and gamma dose from Sri Lankan clay bricks used in building construction, Appl. Radiat. Isot. 54 (2001) 365-369, http:// dx.doi.org/10.1016/S0969-8043(00)00107-X.

[37] M.S. El-Tahawy, R.H. Higgy, Natural radioactivity in different types of bricks fabricated and used in the Cairo region. Appl. Radiat. Isot. 46 (1995) 14011406, http://dx.doi.org/10.1016/0969-8043(95)00220-8.

[38] V. Kumar, T.V. Ramachandran, R. Prasad, Natural radioactivity of Indian building materials and by-products, Appl. Radiat. Isot. 51 (1999) 93-96, http://dx.doi.org/10.1016/S0969-8043(98)00154-7.

[39] S. Righi, L. Bruzzi, Natural radioactivity and radon exhalation in building materials used in Italian dwellings, J. Environ. Radioact. 88 (2006) 158-170, http://dx.doi.org/10.1016/j.jenvrad.2006.01.009.

[40] L. Fior, J. Nicolosi Corrĉa, S.A. Paschuk, V.V. Denyak, H.R. Schelin, B.R. Soreanu Pecequilo, J. Kappke, Activity measurements of radon from construction materials, Appl. Radiat. Isot. 70 (2012) 1407-1410, http://dx.doi.org/10.1016/ j.apradiso.2011.11.036.

[41] K. Vanasundari, R. Ravisankar, D. Durgadevi, R. Kavita, M. Karthikeyan, Measurement of natural radioactivity in building material used in Chengam 
of Tiruvannamalai district, Tamilnadu by gamma-ray spectrometry, Indian J. Adv. Chem. Sci. (2012) 22-27.

[42] R. Mehra, R.G. Sonkawade, K. Badgan, S. Singh, Measurement of natural radioactivity in rock samples using gamma ray spectrometry, Asian J. Chem. 21 (2009) S212-S215. http://asianjournalofchemistry21102009. weebly.com/uploads/2/9/7/1/2971446/046-s212-s215.pdf.

[43] B. Kerur, T. Rajeshwari, N. Nagabhushana, S. Anilkumar, K. Narayani, A. Rekha, B. Hanumaiah, Natural radioactivity levels in some environmental samples of Shahpur Region of North Karnataka, India, Radiat. Prot. Environ. 34 (2011) 55-59. http://rpe.org.in/temp/RadiatProtEnviron34155-2233622_061216. pdf.

[44] C. Vamoussa, S. Joseph, K. N`Dri, K.A. Antonin, O. Samuel, B. Stephane, Measurement of natural radioactivity in the clays consummated in Cote d'Ivoire using gamma-ray spectrometry, J. Appl. Sci. 13 (2013) 140-146, http://dx.doi.org/10.3923/jas.2013.140.146.

[45] S. Ali, M. Tufail, K. Jamil, A. Ahmad, H.A. Khan, Gamma-ray activity and dose rate of brick samples from some areas of North West Frontier Province (NWFP), Pakistan, Sci. Total Environ. 187 (1996) 247-252, http://dx.doi.org/ 10.1016/0048-9697(96)05109-1.

[46] R.H. Higgy, M.S. El-Tahawy, A.T. Abdel-Fattah, U.A. Al-Akabawy, Radionuclide content of building materials and associated gamma dose rates in Egyptian dwellings, J. Environ. Radioact. 50 (2000) 253-261, http://dx.doi.org/10.1016/ S0265-931X(00)00017-5.

[47] R. Ravisankar, Y. Raghu, A. Chandrasekaran, M. Suresh Gandhi, P. Vijayagopal, B. Venkatraman, Determination of natural radioactivity and the associated radiation hazards in building materials used in Polur, Tiruvannamalai District, Tamilnadu, India using gamma ray spectrometry with statistical approach, J. Geochemical Explor. 163 (2016) 41-52, http://dx.doi.org/ 10.1016/j.gexplo.2016.01.013.

[48] B. Mavi, I. Akkurt, Natural radioactivity and radiation hazards in some building materials used in Isparta, Turkey, Radiat. Phys. Chem. 79 (2010) 933-937, http://dx.doi.org/10.1016/j.radphyschem.2010.03.019.

[49] O. Baykara, S. Karatepe, M. Doğru, Assessments of natural radioactivity and radiological hazards in construction materials used in Elazig, Turkey, Radiat. Meas. 46 (2011) 153-158, http://dx.doi.org/10.1016/j.radmeas.2010.08.010.

[50] P. Ujić, I. Čeliković, A. Kandić, I. Vukanac, M. Durašević, D. Dragosavac, Z.S Žunić, Internal exposure from building materials exhaling 222Rn and 220Rn as compared to external exposure due to their natural radioactivity content, Appl. Radiat. Isot. 68 (2010) 201-206, http://dx.doi.org/10.1016/j. apradiso.2009.10.003.

[51] R. Ravisankar, K. Vanasundari, M. Suganya, Y. Raghu, A. Rajalakshmi, A. Chandrasekaran, S. Sivakumar, J. Chandramohan, P. Vijayagopal, B. Venkatraman, Multivariate statistical analysis of radiological data of building materials used in Tiruvannamalai, Tamilnadu, India, Appl. Radiat. Isot. 85 (2014) 114-127, http://dx.doi.org/10.1016/j.apradiso.2013.12.005.

[52] M.A. Uosif, S. Issa, A.A. Ebrahim, E.M. Zahran, M. Moussa, Determination of natural radioactivity in building raw materials from the quarries of Assiut cement company, Assiut, Egypt, Int. J. New Horizons Phys. 32 (2014) 25-32, http://dx.doi.org/10.12785/ijnhp/010104.

[53] W.R. Alharbi, A. El-Taher, Elemental analysis and natural radioactivity levels of clay by gamma ray spectrometer and instrumental neutron activation analysis, Sci. Technol. Nucl. Install. 2016 (2016) 1-5, http://dx.doi.org/ $10.1155 / 2016 / 8726260$.

[54] N. Ibrahim, Natural activities of $238 \mathrm{U}, 232 \mathrm{Th}$ and $40 \mathrm{~K}$ in building materials, J. Environ. Radioact. 43 (1999) 255-258, http://dx.doi.org/10.1016/S13504487(03)00173-2.

[55] A. Kumar, M. Kumar, B. Singh, S. Singh, Natural activities of 238U, 232Th and $40 \mathrm{~K}$ in some Indian building materials, Radiat. Meas. 36 (2003) 465-469, http://dx.doi.org/10.1016/S1350-4487(03)00173-2.

[56] A. Eštoková, L. Palaščáková, Study of natural radioactivity of Slovak cements, Chem. Eng. Trans. 32 (2013) 1675-1680, http://dx.doi.org/10.3303/ CET1332280.

[57] C. Nuccetelli, Y. Pontikes, F. Leonardi, R. Trevisi, New perspectives and issues arising from the introduction of (NORM) residues in building materials: a critical assessment on the radiological behaviour, Constr. Build. Mater. 82 (2015) 323-331, http://dx.doi.org/10.1016/j.conbuildmat.2015.01.069.

[58] K. Khan, H.M. Khan, Natural gamma-emiting radionuclides in Pakistani Portland cement, Appl. Radiat. Isot. 54 (2001) 861-865, http://dx.doi.org/ 10.1016/S0969-8043(00)00327-4.

[59] C. Nuccetelli, C. Bolzan, In situ gamma spectroscopy to characterize building materials as radon and thoron sources, Sci. Total Environ. 272 (2001) 355360, http://dx.doi.org/10.1016/S0048-9697(01)00718-5.

[60] D.O. Kpeglo, H. Lawluvi, A. Faanu, A.R. Awudu, P. Deatanyah, S.G. Wotorchi, Natural radioactivity and its associated radiological hazards in Ghanaian cement, Res. J. Environ. Earth Sci. 3 (2015) 160-166.

[61] B. Kucukomeroglu, A. Kurnaz, N. Damla, U. Cevik, N. Celebi, B. Ataksor, H. Taskin, Environmental radioactivity assessment for Bayburt, Turkey, J. Radiol. Prot. 29 (2009) 417-428, http://dx.doi.org/10.1088/0952-4746/29/3/006.

[62] K. Iwaoka, M. Hosoda, N. Suwankot, Y. Omori, T. Ishikawa, H. Yonehara, S. Tokonami, Natural radioactivity and radon exhalation rates in man-made tiles used as building materials in Japan, Radiat. Prot. Dosimetry. 31 (2015) 491-495, http://dx.doi.org/10.1093/rpd/ncv230.

[63] J.A. Ademola, Natural radioactivity and hazard assessment of imported ceramic tiles in Nigeria, African J. Biomed. Res. 12 (2009) 161-165, http://dx. doi.org/10.4314/ajbr.v12i3.
[64] G. Senthilkumar, Y. Raghu, S. Sivakumar, A. Chandrasekaran, D. Prem Anand, R. Ravisankar, Natural radioactivity measurement and evaluation of radiological hazards in some commercial flooring materials used in Thiruvannamalai, Tamilnadu, India, J. Radiat. Res. Appl. Sci. 7 (2014) 116122, http://dx.doi.org/10.1016/j.jrras.2013.12.009.

[65] L. Bruzzi, M. Baroni, G. Mazzotti, R. Mele, S. Righi, Radioactivity in raw materials and end products in the Italian ceramics industry, J. Environ. Radioact. 47 (2000) 171-181, http://dx.doi.org/10.1016/S0265-931X(99) 00026-0.

[66] R. Shweikani, G. Raja, Radon exhalation from some finishing materials frequently used in Syria, Radiat. Meas. 44 (2009) 1019-1023, http://dx.doi org/10.1016/j.radmeas.2009.10.034.

[67] M. Tufail, N. Ahmad, S. Almakky, M.S. Zafar, H.A. Khan, Natural radioactivity in the ceramics used in dwellings as construction material, Sci. Total Environ. 127 (1992) 243-253, http://dx.doi.org/10.1016/0048-9697(92)90506-N.

[68] K. Kovler, Legislative aspects of radiation hazards from both gamma emitters and radon exhalation of concrete containing coal fly ash, Constr. Build. Mater. 25 (2011) 3404-3409, http://dx.doi.org/10.1016/j.conbuildmat.2011.03.031.

[69] J.A. Ademola, P.O Oguneletu, Radionuclide content of concrete building blocks and radiation dose rates in some dwellings in Ibadan, Nigeria, J. Environ. Radioact. 81 (2005) 107-113, http://dx.doi.org/10.1016/ j.jenvrad.2004.12.002.

[70] D. liang He, G. fu Yin, F. qin Dong, L. bao Liu, Y. jun Luo, Research on the additives to reduce radioactive pollutants in the building materials containing fly ash, J. Hazard. Mater. 177 (2010) 573-581, http://dx.doi.org/ 10.1016/j.jhazmat.2009.12.071.

[71] N. Damla, U. Cevik, A.I. Kobya, A. Celik, R. Van Grieken, Y. Kobya, Characterization of gas concrete materials used in buildings of Turkey, J. Hazard. Mater. 168 (2009) 681-687, http://dx.doi.org/10.1016/j. jhazmat.2009.02.092.

[72] A. El-Shershaby, Study of radioactivity levels in granite of Gable Gattar II in the north eastern desert of Egypt, Appl. Radiat. Isot. 57 (2002) 131-135, http://dx.doi.org/10.1016/S0969-8043(02)00067-2.

[73] S. Pavlidou, A. Koroneos, C. Papastefanou, G. Christofides, S. Stoulos, M Vavelides, Natural radioactivity of granites used as building materials, J. Environ. Radioact. 89 (2006) 48-60, http://dx.doi.org/10.1016 j.jenvrad.2006.03.005

[74] M. Tzortzis, H. Tsertos, S. Christofides, G. Christodoulides, Gamma radiation measurements and dose rates in commercially-used natural tiling rocks (granites), J. Environ. Radioact. 70 (2003) 223-235, http://dx.doi.org/10.1016/ S0265-931X(03)00106-1.

[75] G. Carrera, M. Garavaglia, S. Magnoni, G. Valli, R. Vecchi, Natural radioactivity and radon exhalation in stony materials, J. Environ. Radioact. 34 (1997) 149159, http://dx.doi.org/10.1016/0265-931X(96)00025-2.

[76] F. Asgharizadeh, A. Abbasi, O. Hochaghani, E.S. Gooya, Natural radioactivity in granite stones used as building materials in Iran, Radiat. Prot. Dosimetry. 149 (2012) 321-326, http://dx.doi.org/10.1093/rpd/ncr233.

[77] Ş. Turhan, Estimation of possible radiological hazards from natural radioactivity in commercially-utilized ornamental and countertops granite tiles, Ann. Nucl. Energy 44 (2012) 34-39, http://dx.doi.org/10.1016/j. anucene.2012.01.018.

[78] A.I. Abd El-mageed, A.H. El-Kamel, A. Abbady, S. Harb, A.M.M. Youssef, I.I. Saleh, Assessment of natural and anthropogenic radioactivity levels in rocks and soils in the environments of Juban town in Yemen, Radiat. Phys. Chem. 80 (2011) 710-715, http://dx.doi.org/10.1016/j.radphyschem.2011.02.025.

[79] R.M. Anjos, J. Juri Ayub, A.S. Cid, R. Cardoso, T. Lacerda, External gamma-ray dose rate and radon concentration in indoor environments covered with Brazilian granites, J. Environ. Radioact. 102 (2011) 1055-1061, http://dx.doi. org/10.1016/j.jenvrad.2011.06.001.

[80] P. Bala, R. Mehra, R.C. Ramola, Distribution of natural radioactivity in soil samples and radiological hazards in building material of Una, Himachal Pradesh, J. Geochemical Explor. 142 (2014) 11-15, http://dx.doi.org/10.1016/ j.gexplo.2014.02.010.

[81] C.-J. Chen, Y.-M. Lin, Assessment of building materials for compliance with regulations of ROC, Environ. Int. 22 (1996) 221-226, http://dx.doi.org/ 10.1016/S0160-4120(96)00111-0.

[82] R. Ribeiro, A.C. Universit, F. Metro, P. Energ, Activity concentrations of natural radionuclides in commercial granite samples from Espírito Santo State, Brazil Int. Nucl. Saf. J. 4 (2015) 53-58.

[83] N.M. Hassan, T. Ishikawa, M. Hosoda, A. Sorimachi, S. Tokonami, M. Fukushi, S.K. Sahoo, Assessment of the natural radioactivity using two techniques for the measurement of radionuclide concentration in building materials used in Japan, J. Radioanal. Nucl. Chem. 283 (2010) 15-21, http://dx.doi.org/10.1007/ s10967-009-0050-6.

[84] A.A. Qureshi, I.A.K. Jadoon, A.A. Wajid, A. Attique, A. Masood, M. Anees, S Manzoor, A. Waheed, A. Tubassam, Study of natural radioactivity in Mansehra granite, Pakistan: environmental concerns, Radiat. Prot. Dosimetry 158 (2014) 466-478, http://dx.doi.org/10.1093/rpd/nct271.

[85] R. Kardos, Z. Sas, M. Hegedus, A. Shahrokhi, J. Somlai, T. Kovacs, Radionuclide content of NORM by-products originating from the coal-fired power plant in Oroszlány (Hungary), Radiat. Prot. Dosimetry 167 (2015) 266-269, http://dx doi.org/10.1093/rpd/ncv259.

[86] A.K. Hassan, S. Fares, M. Abd El-Rahma, Natural radioactivity levels and radiation hazards for gypsum materials used in Egypt, J. Environ. Sci. Technol. 7 (2013) 56-66, http://dx.doi.org/10.3923/jest.2014.56.66. 
[87] R. García-Tenorio, J.P. Bolivar, M.J. Gazquez, J. Mantero, Management of byproducts generated by NORM industries: towards their valorization and minimization of their environmental radiological impact, J. Radioanal. Nucl. Chem. 306 (2015) 641-648, http://dx.doi.org/10.1007/s10967-015-4263-6.

[88] C. Heidrich, S. Brown, D. Collier, Naturally occurring radionuclides in Australian coal combustion products (CCPs), in: Proceeding World Coal Ash Conf. - May 9-12, Denver, 2011.

[89] M. Nisnevich, G. Sirotin, T. Schlesinger, Y. Eshel, Radiological safety aspects of utilizing coal ashes for production of lightweight concrete, Fuel 87 (2008) 1610-1616, http://dx.doi.org/10.1016/j.fuel.2007.07.031.

[90] U. Cevik, N. Damla, B. Koz, S. Kaya, Radiological characterization around the Afsin-Elbistan coal-fired power plant in Turkey, Energy Fuels 22 (2008) 428432, http://dx.doi.org/10.1021/ef700374u.

[91] A.K. Mahur, R. Kumar, D. Sengupta, R. Prasad, Estimation of radon exhalation rate, natural radioactivity and radiation doses in fly ash samples from Durgapur thermal power plant, West Bengal, India, J. Environ. Radioact. 99 (2008) 1289-1293, http://dx.doi.org/10.1016/j.jenvrad.2008.03.010.

[92] R.C. Bhangare, M. Tiwari, P.Y. Ajmal, S.K. Sahu, G.G. Pandit, Distribution of natural radioactivity in coal and combustion residues of thermal power plants, J. Radioanal. Nucl. Chem. 300 (2014) 17-22, http://dx.doi.org/10.1007/ s10967-014-2942-3.

[93] D.J. Karangelos, N.P. Petropoulos, M.J. Anagnostakis, E.P. Hinis, S.E. Simopoulos, Radiological characteristics and investigation of the radioactive equilibrium in the ashes produced in lignite-fired power plants, J. Environ.

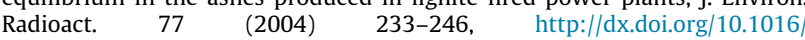
j.jenvrad.2004.03.009.

[94] K. Realo, E. Realo, Radionuclides in Estonian oil-shale and oil-shale ashes, Proc. IRPA Reg. Symp. Radiat. Prot. Neighb. Ctries. Cent. Eur. (1997) 161-164

[95] M. Gupta, A.K. Mahur, R. Varshney, R.G. Sonkawade, K.D. Verma, R. Prasad, Measurement of natural radioactivity and radon exhalation rate in fly ash samples from a thermal power plant and estimation of radiation doses, Radiat. Meas. 50 (2013) 160-165, http://dx.doi.org/10.1016/j. radmeas.2012.03.015.

[96] L.M. Singh, M. Kumar, B.K. Sahoo, B.K. Sapra, R. Kumar, Study of natural radioactivity, radon exhalation rate and radiation doses in coal and fly ash samples from thermal power plants, India, Phys. Procedia. 80 (2015) 120124, http://dx.doi.org/10.1016/j.phpro.2015.11.070.

[97] A.K. Mahur, R. Kumar, M. Mishra, D. Sengupta, R. Prasad, An investigation of radon exhalation rate and estimation of radiation doses in coal and fly ash samples, Appl. Radiat. Isot. 66 (2008) 401-406, http://dx.doi.org/10.1016/j. apradiso.2007.10.006.

[98] G. Skodras, D. Karangelos, M. Anagnostakis, E. Hinis, P. Grammelis, E. Kakaras, Coal fly-ash utilisation in Greece, in: Proceeding World Coal Ash Conf. - April 11-15, Lexington, 2005: pp. 1-18.

[99] P.S. Chang, T.C. Chu, Y.M. Lin, Environmental radiation from a coal-fired power plant using domestically produced coals, J. Radiat. Res. 23 (1982) 283289, http://dx.doi.org/10.1269/jrr.23.283.

[100] P. Grammelis, G. Skodras, E. Kakaras, D.J. Karangelos, N.P. Petropoulos, M.J. Anagnostakis, E.P. Hinis, S.E. Simopoulos, Effects of biomass co-firing with coal on ash properties. Part II: Leaching, toxicity and radiological behaviour, Fuel 85 (2006) 2316-2322, http://dx.doi.org/10.1016/j.fuel.2006.01.035.

[101] Vigh Tamas, Föld alatti bányaüzem radiológiai vizsgálata a Mangán KFT példáján (PhD thesis in Hungarian), University of Pannonia, 2011. http:// konyvtar.uni-pannon.hu/doktori/2011/Vigh_Tamas_dissertation.pdf.

[102] T. Kovacs, A. Shahrokhi, Z. Sas, T. Vigh, J. Somlai, Radon exhalation study of manganese clay residue and usability in brick production, J. Environ. Radioact. 168 (2017) 15-20, http://dx.doi.org/10.1016/j.jenvrad.2016.07.014.

[103] F. Gezer, S. Turhan, F.A. Uğur, E. Gören, M.Z. Kurt, Y. Ufuktepe, Natura radionuclide content of disposed phosphogypsum as TENORM produced from phosphorus fertilizer industry in Turkey, Ann. Nucl. Energy 50 (2012) 33-37, http://dx.doi.org/10.1016/j.anucene.2012.07.018.

[104] Z. Sas, J. Somlai, G. Szeiler, T. Kovacs, Usability of clay mixed red mud in Hungarian building material production industry, J. Radioanal. Nucl. Chem. 306 (2015) 271-275, http://dx.doi.org/10.1007/s10967-015-3966-z.

[105] H. Gu, N. Wang, S. Liu, Radiological restrictions of using red mud as building material additive, Waste Manag. Res. 30 (2012) 961-965, http://dx.doi.org/ $10.1177 / 0734242 \times 12451308$.

[106] M. Hushari, I.A. Alsadig, H. Al-sulaiti, Measurements of recycling steel slag at Qatar steel using low-level gamma-ray spectrometry and calculation of risk factors, Donnish J. Res. Environ. Stud. 2 (2015) 28-36.

[107] T. Sofilić, D. Barišić, U. Sofilić, Natural radioactivity in steel slag aggregate, Arch. Metall. Mater. 56 (2011) 627-634, http://dx.doi.org/10.2478/v10172011-0068-y.

[108] T. Sofilic, D. Bariši, Ž. Grahek, Š. Cerjan-Stefanovic, A. Rastov, B. Mio, Radionuclides in metallurgical products and waste, Acta Metall. Slovaca 10 (2004) 29-35.

[109] Y. Benjamini, Opening the Box of a Boxplot, Am. Stat. 42 (1988) 257-262, http://dx.doi.org/10.2307/2685133. 